\title{
Supplemental Feeding and Food Plots for Bobwhite Quail1
}

William M. Giuliano, James F. Selph, Robert Hoffman, and Brandon J. Schad ${ }^{2}$

If food is the most limiting habitat component for quail and other habitat components are available (for example, escape cover), food supplementation may help them (Figure 1). When contemplating an artificial feeding program, consider the needs of quail during different seasons (for example, the need for high protein during the breeding season) and what is available or lacking naturally within a bird's home range. While abundant and easily accessible foods are needed year-round, they may be particularly important during winter and the breeding season.

\section{Feeders}

Providing food for quail through feeders has had mixed results for bobwhite populations (Figure 2). This practice may be detrimental because it concentrates birds, making them easier to prey upon and facilitating the spread of disease. Given that such feeding programs have often not benefited quail populations and considering their high cost, care should be taken in using them. Foods typically provided in feeders include corn, sorghum, and commercial game bird feed mixes.

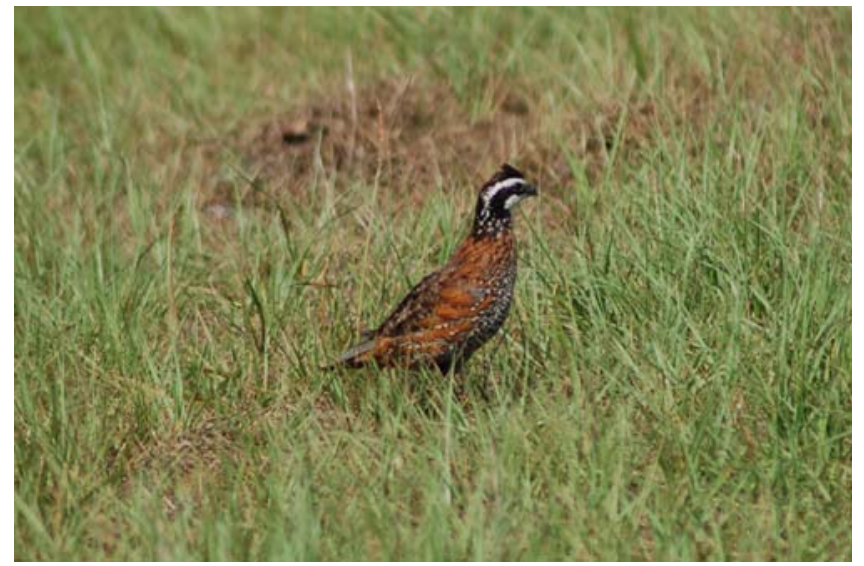

Figure 1. If food is the most limiting habitat component for quail, food supplementation can help bolster populations, if other habitat components such as cover and water are available. Credits: W.M. Giuliano.

\section{Spreading Feed}

Recent work in north Florida by Tall Timbers Research Station has shown more promise at benefiting bobwhite populations with the spreading of feed through good quality cover, which includes vegetation that provides overhead cover with relatively bare ground below (Figure 3). Preliminary findings suggest it can improve quail survival and

1. This document is WEC 224 and one of a series of the Department of Wildlife Ecology and Conservation, Florida Cooperative Extension Service, Institute of Food and Agricultural Sciences (IFAS), University of Florida. First published: June 2007. Please visit the EDIS Web site at http://edis.ifas.ufl.edu for more publications.

2. William M. Giuliano is a Professor and Wildlife Extension Specialist; James F. Selph is the Desoto County Extension Director; and Robert Hoffman and Brandon J. Schad are Graduate Students; Cooperative Extension Service, Institute of Food and Agricultural Sciences, University of Florida, Gainesville, FL 32611 . 


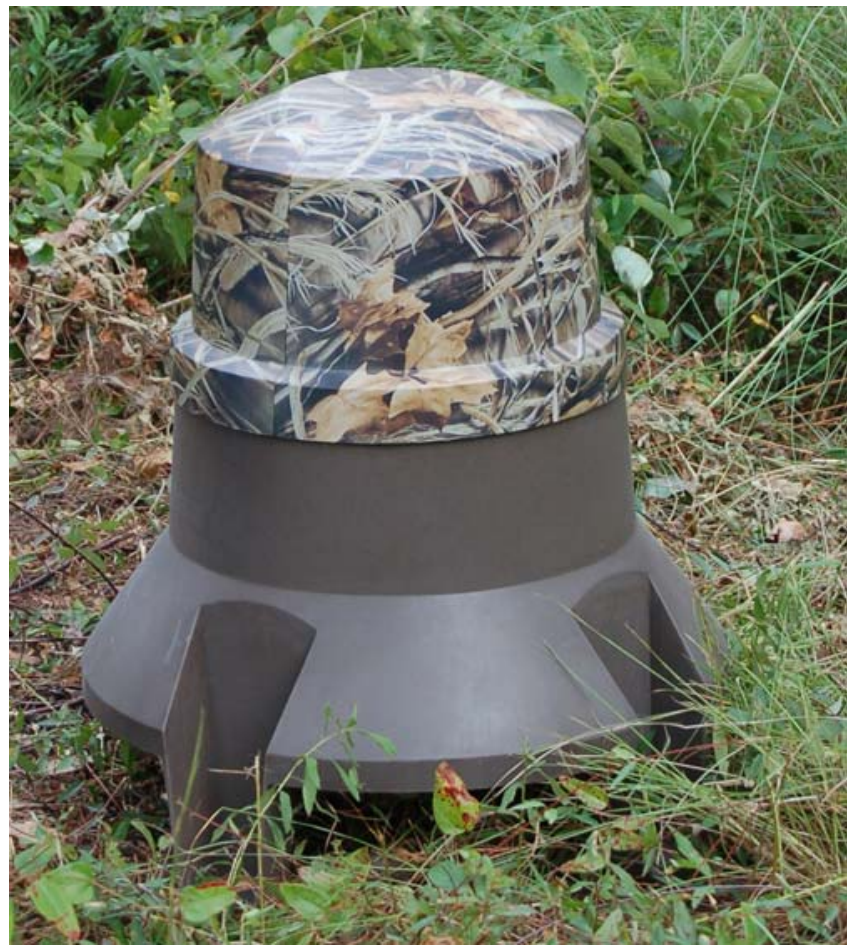

Figure 2. Providing forage to bobwhites via feeders is expensive and has had mixed results. Credits: W.M. Giuliano.

reproduction in some years and locations, but not all. Spreading feed appears to help in years when native food production is very low, by keeping quail populations from crashing as far as they would without supplemental feed. However, this practice has no effect in years with good natural food crops or in quality habitats. Spreading feed through or adjacent to quality cover allows birds to spend less time foraging and to forage in protective cover, both of which reduce predation. In addition, dispersing feed through large areas of cover does not concentrate birds at predictable locations, as with feeders, and may reduce the associated effects of predation and disease spread. When choosing types of feed, consider cost, size, quality (energy and protein content), ease of application, and durability in the field. For example, grain sorghum may be better than corn because it is higher in protein, has smaller grains that are easier for quail to consume, and does not mold as easily. Tall Timbers Research Station has had success spreading sorghum twice per month throughout the year at a rate of 1.5 bushels/acre/year from a tractor.

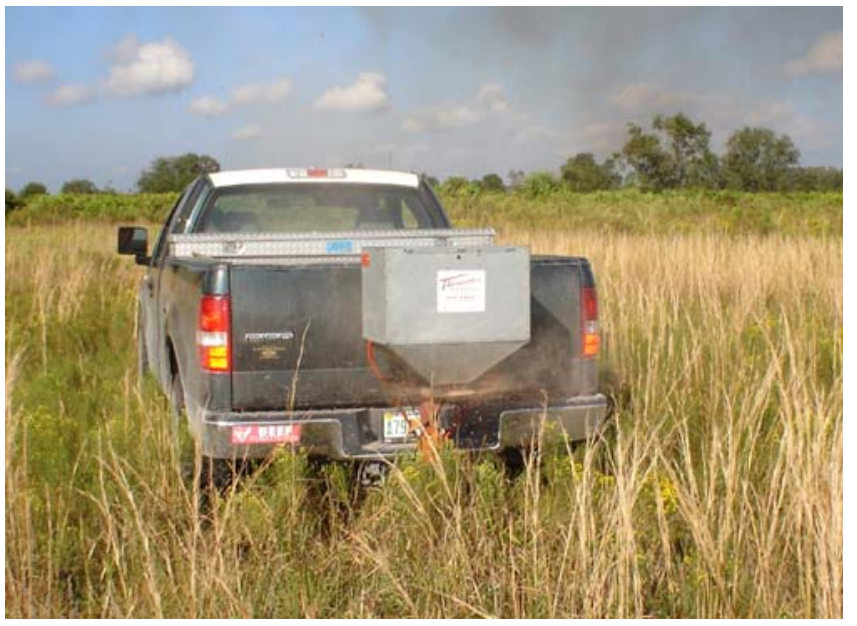

Figure 3. Providing supplemental feed to bobwhites by spreading it in or near cover may benefit quail populations when natural foods are scarce. Credits: B.J. Schad.

\section{Food Plots}

Supplementing native quail foods with plantings can improve an area for bobwhites (Figure 4). Planting legumes and other plants that are high in protein and attract insects works best. Food plots not only feed adults, but if legumes and other plants are used to attract insects, they can provide important food for chicks. This is particularly true during the spring and summer when breeding females and growing chicks need insects to meet high protein demands. The use of plants that provide not only food but also cover are best, because they can obtain protection from predators and extreme climatic conditions while foraging. Ideally, food plots will contain a mixture of species that grow and mature throughout the entire year. This will not only provide food throughout the year, but also protect against failures of individual plant species, which could lead to barren, useless plots when using single species. Ideally, quail food plots will be long strips, 10-20 feet wide, 0.1 to 0.25 acres in size, adjacent to escape cover (including thick tangles of shrubs and other woody vegetation) and other habitats (such as field borders, fence rows, etc.), distributed throughout the landscape at a rate of 1 plot/15-20 acres, produce at least $200 \mathrm{lbs} /$ acre of seed, and will attract abundant and diverse insect assemblages. If larger and wider plots are used, it is important that escape and foraging cover be provided within the plot.

A wide variety of plants has been successfully used in quail food plots throughout the bobwhites 


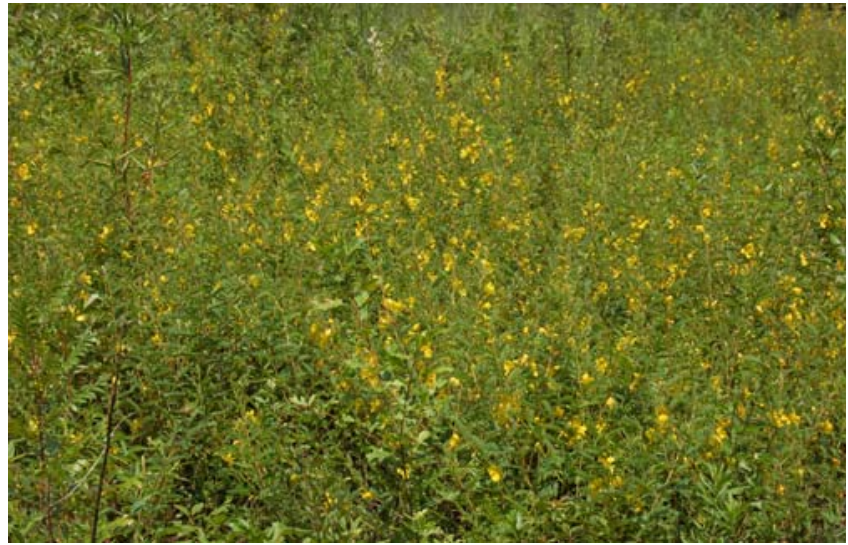

Figure 4. Supplementing native quail foods with plantings, such as partridge pea, in food plots can improve an area for bobwhites. Credits: W.M. Giuliano.

range, with many commercial mixes available. However, poor soil and extreme weather conditions in parts of central and south Florida severely limit what species (for example, partridge pea) can be effectively used, including most commercial mixes. Each plant and mix requires different site preparation and maintenance (such as disking and cultipacking), and has different costs. It is important to test soils for both $\mathrm{pH}$ and fertility, and apply lime and fertilizer as needed for proper food plot establishment. Proper fertility will require balanced major nutrients (nitrogen, phosphorus, and potassium), as well as secondary and micro-nutrients (calcium, magnesium, manganese, etc.). For many legumes, it will also be important to inoculate the seed properly before planting. Timely mowing and selective herbicide applications may also be necessary to control undesirable plant competition during establishment. It may be necessary to plant food plots twice per year as some plants are non-reseeding annuals and may only grow during either the cool or warm seasons. Table 1 contains a list of common food plots plants for bobwhites in Florida.

In areas with proper soil and environmental conditions, with perennial or reseeding annual plants, and where native forbs (for example, ragweed) and legumes (for, example partridge pea) readily establish themselves, plots may not have to be replanted each year. In many cases, allowing plots to go fallow for 1-2 years can produce a food plot of equal or greater value to quail than a new planting, saving considerable time and money. In many areas of central and south Florida, this will not be possible.
Information on planting recommendations for specific species can be found in the following publications at the Florida Cooperative Extension publications web site (http://edis.ifas.ufl.edu/):

- Establishment of food plots for white-tailed deer in central and south Florida

- Selected legumes used as summer cover crops

- Establishing and maintaining wildlife food sources

-2006-2007 - wildlife forages for north Florida - Part 1: cool season food plots

- A walk on the wild side: 2006-2007 cool-season forage recommendations for wildlife food plots in north Florida

- Soil fertility management for wildlife food plots

Table 1. Common food plot plants for bobwhites in Florida.

\begin{tabular}{|ll|}
\hline \hline \multicolumn{1}{|c}{ Common Name } & \multicolumn{1}{c|}{ Scientific Name } \\
\hline Partridge pea* & Chamaecrista spp. \\
Cowpeas* $^{*}$ Caley pea* & Vigna spp. \\
Winter pea* & Lathyrus hirsutus \\
Lespedezas* & Pisum sativum \\
Clovers* $^{*}$ & Lespedeza spp. \\
Alyceclover* & Trifolium spp. \\
Joint or Deer vetchs* & Alysicarpus vaginalis \\
Vetchs* & Aeschynomene spp. \\
Beggarweeds* & Vicia spp. \\
Birdsfoot trefoil* & Desmodium spp. \\
Panic grasses (millets) & Lotus corniculatus \\
& Panicum spp. \& \\
Foxtail grasses (millets) & Dicanthelium spp. \\
Buckwheat & Setaria spp. \\
Corn & Fagopyrum esculentum \\
Soybean & Zea mays \\
Sorghums (milos) & Glycine max \\
Wheat & Sorghum spp. \\
Rye & Triticum aestivum \\
Oats & Secale cereale \\
Dogwoods & Avena spp. \\
Blueberries & Cornus spp. \\
Blackberries & Vaccinium spp. \\
Other soft mast (fruits) & Rubus spp. \\
\hline * Legumes & \\
\hline \hline
\end{tabular}

